\title{
Compromise between mining activities and reuse of recycled aggregates for development of sustainable local planning. (Sardinia)
}

\author{
G. Balletto, S. Naitza, G. Mei, C. Furcas
}

\begin{abstract}
Despite its economic importance, mining activity for aggregate production (sand, gravel and crushed stone), may lead to an over-exploitation of the natural environment. This paper aims to evaluate the needs of aggregates associated with urban plans for the municipalities of Cagliari, Tortolì and Sant'Antioco (Sardinia island, Italy), also identifying the potential for recycling of construction and demolition waste, in particular of concrete. The geographical position of Sardinia prevents trade of recycled aggregates, confirming that the whole needs of aggregates can economically be satisfied only by local products. In order to meet the demand for aggregates from building industry and infrastructures, the combined use of natural and recycled aggregates, although desirable (EU Parliament, 2008), is not really suitable. It was therefore proposed another way, based on keeping the levy of recycled aggregates closely linked to the implementation of urban plans through the introduction of a new parameter, the Aggregate Maximum (Fi -max).
\end{abstract}

\section{Introduction}

In western Europe, the stock of natural resources has been overexploited for centuries, even though they actually are non-renewable. In particular, mining and quarrying are industrial activities which, by their very nature, may cause irreversible changes to the territory, leaving behind degraded areas and leading to the impoverishment of the environment (Fondazione Benetton Studi Ricerche and IBA, 2005; Gisotti, 2008). Also, an improper management of these activities may give rise to the risk of hazardous consequences on the environment, especially from the points of view of the industrial processing and the management of waste produced. This work will investigate on a more sustainable and environmental-aware way to produce a particular stream of raw materials, that is aggregates (sand, gravel and crushed stone). Aggregates are mostly used in the construction sector, either in raw form as road or railway ballasts, or in the production of high-quality materials such as concrete, asphalt or pre-cast products. In order to meet the demand for this kind of minerals, every year about 2 billion cubic metres of aggregates are produced in the European Union (UEPG, 2012). The European per capita production of construction aggregates shows a general increase, with a value estimated at about 6 tons/inhabitant with reference to the year 2007 (Furcas and Balletto, 2012). One possible solution to the environmental costs of the aggregate production can be to satisfy a part of the demand for construction aggregates by evaluating the recycling potential of Construction \& Demolition Waste (CDW) (Pani and Francesconi, 2011).

In the light of this, recycled aggregates (RA) can be produced from CDW and re-used in the same field, the construction sector. This practice tends to be common in those countries in which both high residential density and the shortage of mineral raw materials reduce the chances to find new quarry sites.

In addition, meeting a part of the demand for natural resources through the use of AR is strictly recommended by the European regulations (EU Parliament, 2008), which state that Members States should reach by 2020 a recovery rate of $70 \%$ by weight of waste produced. Following this, the recycling of aggregates is increasingly growing in some European countries. Some States, including Denmark, the Netherlands, and Germany, have been able to recycle more than $70 \%$ of their own CDW since the mid-nineties (European Parliament, 2008). For instance, Germany had a recycling rate of $89.2 \%$ in 2007 (Spies, 2009), whereas Denmark has recently adopted a landfill tax which has consequently fostered the recycling of CDW. However, in some other countries such as Italy this practice is still so little diffused that it is very difficult to determine the amount of RA obtained from the recycling of CDW. Furthermore, most of RA is used in road filling or railway ballast, whereas their use in concrete is virtually non-existent.

This work will study the situation of the Sardinia region, in which CDW accounted for about 1,127,644 tons in 2008 (Regione Autonoma Sardegna, 2012). Due to its geographic conditions of insularity, Sardinia is compelled to cover the demand for aggregates by the extraction of its own raw materials. Therefore, Sardinia can be considered as a "closed basin", both as regards the supply of natural and recycled aggregates. This work is a part of a broader research project on the recovery of inert waste for making recycled aggregates to be used to realize the local urban plans. The CDW streams that can be actually destined for the reuse in Sardinia will be estimated by means of a census of the recycling facilities in Sardinia. Also, these amounts will be compared with the assessment of the demand for aggregates in reference to the forecasts of the urban plans of Cagliari, Sant'Antioco e Tortolì. Through these forecasts, the assessment of the demand for aggregates in reference to these municipal territories will be undertaken.

\section{Flows of materials}

\section{II.I. The waste from construction and demolition}

We generally define "waste from construction and demolition" or CDW (Construction and Demolition Wastes corresponding to the macro item ERC 17 of the European Waste Catalogue, excluding hazardous waste and naturally 
occurring material referred to CER 170504 ("earth and rocks other than those mentioned in 170503 "). These wastes are primarily derived from the construction, maintenance and renovation of the building works and the maintenance and construction of road and rail infrastructure.

In Italy waste management is governed by Legislative Decree no. 152/06 (Consolidated Law on Environment) which inserts "the waste resulting from demolition, construction, and waste resulting from excavation activities ..." between special waste. Given their origin, these wastes are characterized by a rather mixed compositional fractions. The most relevant fractions, from the point of view of quantity, are represented by cement, concrete, brick and ceramics. These types of waste, although characterized by great potential for recovery and reuse, are still largely disposed of in landfills or even abandoned illegally.

The European Unin is committed to raise awareness among the member states to adopt tools and initiatives to implement a proper policy for the management of such waste. Prevention, preparation for reuse (introduced by Directive 2008/98 / EC), material recycling and recovery (eg energy) were identified as the most preferred options. The use of landfills is the last and least desirable option (Figure 1).

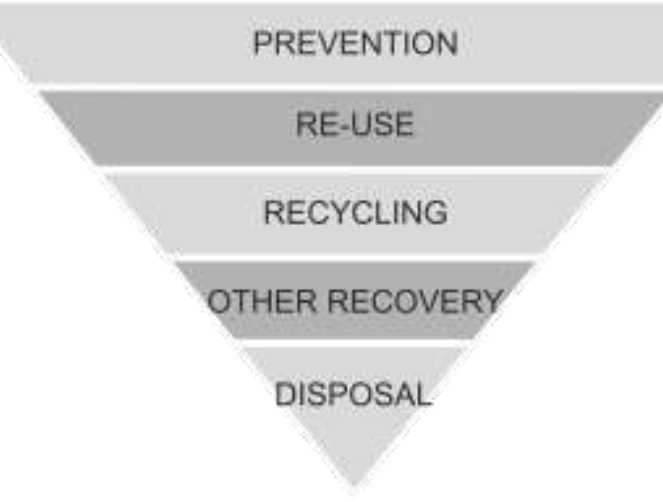

Figure 1 Addresses of the European Directive on Waste, 2008.

The component that we intend to evaluate in the CDW consist of cement, aggregates and concrete. The recycling of this fraction allows to produce so-called Recycled aggregates that can be employed in the construction sector in particular:

- applications without a binder, where the aggregate is used loose (road construction, railway ballast, etc.);

- applications with a binder, where the mixture contains a binding agent, such as cement, bitumen or a substance that has binding properties in contact with water, such as cement (concrete, mortar, etc.).

The introduction of the $\mathrm{CE}$ marking for construction materials, and the publication of harmonized standards on aggregates have officially sanctioned the overcoming of the traditional distinction of the aggregates according to their nature, imposing to evaluate the materials only for their characteristics of performance.

The use of a product resulting from the use of RA can be reasonably identified when the material conforms to certain quality standards (defined by the designer or by specific rules) dependent on the intended use. Compliance with the standards must be guaranteed by a control of the entire recovery process, from the management of incoming waste, through the production process and the applied technologies. Quality evaluation of the process must analyze the final product both from the technical and environmental points of view.

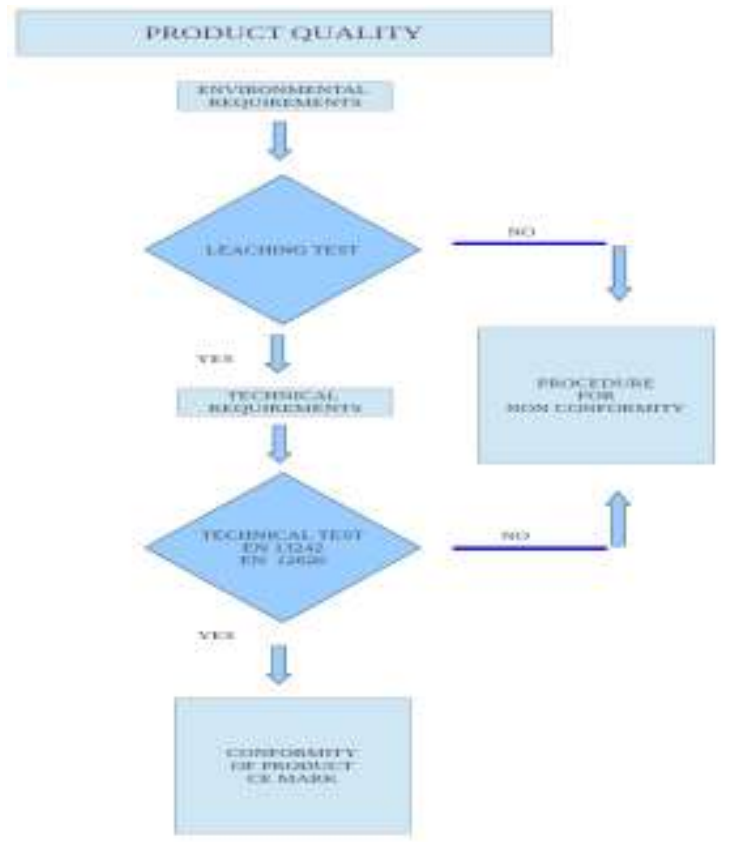

Figure 2 Criteria for the quality of the final product (Bressi et al., 2011).

The aggregates extracted in Italy (sand, gravel, crushed stone for concrete and cement) have been more than 140 million cubic meters in 2009, about 90 million in 2010 and 80 million in 2012. And in parallel, waste from construction and demolition have seen an increase, reaching 45 million tonnes a year, $90 \%$ of which are placed in landfills. The potential impact of recycled aggregates on the total demand for aggregates is about $40 \%$. Factors that should/could favor recycled aggregates over natural ones are:

1) lower prices than those of the natural materials;

2) high demand for materials with low performance (substrates, fills, enticements, detected, etc.);

3) ) limitation of transport costs.

\section{II.II The management of $\mathrm{CDW}$ in Sardinia (Italy)}

To describe the situation of CD W management in Sardinia, the Regional Special Waste Plan approved December 21, $2012 \mathrm{~m} \mathrm{u} \mathrm{s} \mathrm{t} \mathrm{b} \mathrm{e} \mathrm{analyzed;} \mathrm{data} \mathrm{from}$ this instrument refer to the statement MUD (Model of the Environmental Declaration) of 2009, which collects 2008 data (Law 70/94). It is an annual report of the waste produced, processed, transported or sent for disposal in the region. According to these data, CDW production in 2008 amounted to a total of 658, 676, $965 \mathrm{~kg}$, which account for $9 \%$ of the total regional production of hazardous waste and correspond to $670 \mathrm{~kg}$ per capita. It should be noted, however, how this data 
production can be considered only a part of CDW; this is just the amount that is declared by treatment plants. The production of CDW in Sardinia (per capita production of approximately $670 \mathrm{~kg} /$ inhabitant /year) appears to be underevaluated as shown by comparison with the national average (close to $900 \mathrm{~kg} / \mathrm{inhabitant/year),} \mathrm{and}$ by comparison with the data obtained from data analysis of other territories in the national context.

Tables 1 and 2 show the distribution and recovery rates of CDW in Sardinia.

TABLE I.

CDW PRODUCTION IN SARDINIA

\begin{tabular}{|c|c|c|}
\hline Type & Description & Production \\
\hline $\begin{array}{c}\text { CER } \\
170904\end{array}$ & $\begin{array}{l}\text { "Waste mixed } \\
\text { construction and } \\
\text { demolition waste, other } \\
\text { than those referred to in } \\
\text { items 170901, 170902 e } \\
170903\end{array}$ & $352.314 .211 \mathrm{~kg}$ \\
\hline $\begin{array}{c}\text { CER } \\
170107\end{array}$ & $\begin{array}{l}\text { "Mixture of concrete, } \\
\text { bricks, tiles } \\
\text { and ceramics other } \\
\text { than those mentioned } \\
\text { in } 170106\end{array}$ & $120.371 .652 \mathrm{~kg}$ \\
\hline $\begin{array}{c}\text { CER } \\
170405\end{array}$ & "iron and steel" & $120.371 .652 \mathrm{~kg}$ \\
\hline $\begin{array}{c}\text { CER } \\
170101\end{array}$ & "cement" & $79.337 .576 \mathrm{~kg}$ \\
\hline $\begin{array}{c}\text { CER } \\
170302\end{array}$ & $\begin{array}{l}\text { CER } 170302 \\
\text { "bituminous mixtures } \\
\text { other than those } \\
\text { mentioned in 170301" }\end{array}$ & $35.051 .773 \mathrm{~kg}$ \\
\hline
\end{tabular}

TABLE II. RECOVERY RATE AND OBJECTIVES FOR CDW IN SARDINIA (2008), AND OBJECTIVES FOR 2015 AND 2020

$\begin{array}{rccc}\text { Material recovery } & 53.00 \% & 65,00 \% & 70.00 \% \\ \text { Energy recovery } & 10,00 \% & 0,00 & 0,00 \\ \text { Treatment } & 46,70 \% & 35,00 \% & 30,00 \% \\ \text { Disposal } & 46,00 \% & & \end{array}$

The Plan of Special Waste (PRS), in confirming that there are no import/export for CDW in Sardinia, contemplates a series of actions to reduce the generation of waste from construction and demolition, including: the implementation, in the design and execution of the works, of devices and construction techniques that involve less use of raw materials and improve the use of materials that have less impact in quantitative terms of waste production.
From that statement, we proceeded to the identification of the maximum requirements of aggregates resulting from application of the City Urban Planning in the considered municipalities.

\section{Methods}

The evaluation of the needs for aggregates of the municipalities of Cagliari, Sant'Antioco and Tortolì was performed considering the forecasts of the urban development plans; these data were compared with the quantitative flow of CDW produced in Sardinia, allowing to assess the amount of RA that are feasible to meet the requirements.

In particular we proceeded through the following steps:

- Flow analysis from the Special Waste Plan 2012;

- Census of aggregate treatment plants of Sardinia;

- Interviews of managers of the plants;

- Periodic sampling in plant and physical/chemical analyses on CDW samples (Pani et al., 2013);

- Assessment of the needs for aggregates of Cagliari, Sant'Antioco and Tortolì municipalities, derived from forecasts of the City Urban Planning.

- Comparison between quantities produced and estimated requirements, also based on the analysis of the planning instruments.

\section{III.I Aggregate demand for the municipalities of Cagliari, Sant'Antioco and Tortoli}

To meet the demand for aggregates of a given local context, a key step is to know the amount of material consumed in the territory in a given period. Land planning of mining activities shall use this information to estimate the needs of aggregates in a territory. Recently, these plans provide to meet their needs through a forecast of employment of amounts of natural raw materials lower than the estimated total; this in order to facilitate the retrieval of the remaining demand with CDW.

The demand for aggregates of a given territory is intended primarily for private construction and public works, as the construction sector is the largest consumer of aggregates. The literature on the subject (Balletto et al. 2005, Badino et al., 2006) identifies a number of approaches, such as those we have chosen to adopt in this work, i.e. the assessment of inert demand in reference to the previsions of local planning instruments. This method is based in particular on the estimation of the possible consumption of minerals. In the case studies considered (municipalities of Cagliari, Sant'Antioco, Tortolì), the hypothesis that consumption is 
Proc. of the Third Intl. Conf. Advances in Civil, Structural and Mechanical Engineering- CSM 2015

Copyright (C) Institute of Research Engineers and Doctors, USA .All rights reserved. ISBN: 978-1-63248-062-0 doi: 10.15224/ 978-1-63248-062-0-82

equivalent to the demand for aggregates, appears to be properly founded. In fact, Sardinia can rely solely on its own resources, due to the low market value of the aggregates and the high costs of transportation to and from the island. Therefore, established that the market for natural and recycled aggregates refers to a local dimension of the insular type, it follows that consumption is closely linked to the forecasts of the City Urban Planning (PUC). Usually, the PUC refers to a time period of about 10 years. The assessment of the needs for aggregates in each municipality, according to this methodology, is derived from the planned volumes in individual urban zones (expressed in square meters), as shown below:

A zone: Old Town;

B zone: Residential Completion;

C zone: residential expansion

F zone: tourist activities

Found the volumes achievable in single homogeneous areas, and then applying different coefficients of utilization, we deduce the quantity of materials required for the construction of the works planned by the PUC. The estimate of the needs of the City of Cagliari, Sant'Antioco and Tortoli is outlined in Table 3 .

For each urban area, were considered works of new construction and maintenance.

TABLE III. ESTIMATION OF THE NEEDS OF THE MUNICIPALITIES: CAgliari, SANT'ANTIOCO AND TORTOli (City URBAn PlanNing)
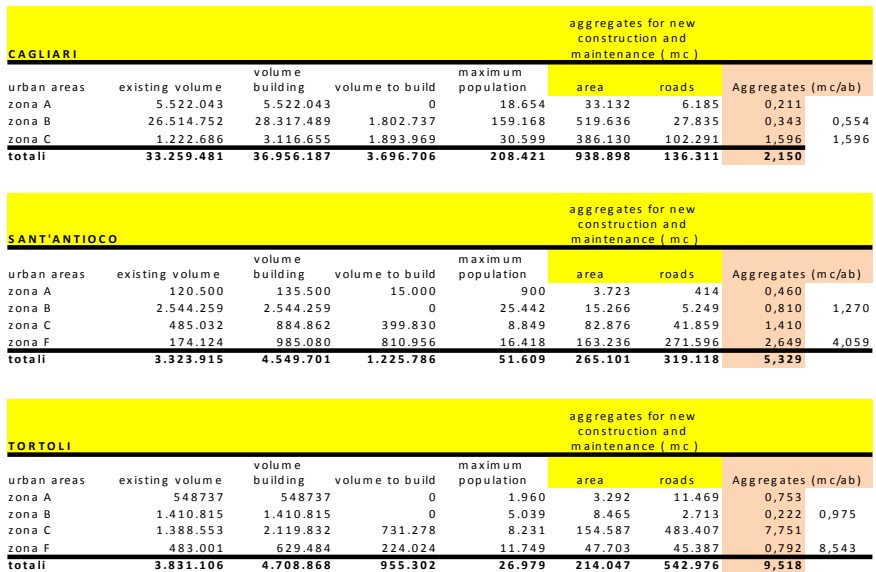

In Table 3 we have not taken into account the D (craft and industrial areas) and $\mathrm{G}$ (general services) zones, in order to focus to residential expansion and tourist areas $(\mathrm{C}$ and $\mathrm{F}$ zones), to compare them with the historical and completion residential types (A and $\mathrm{B}$ zones ), and to contain both the consumption of soil resulting from the expansion and the needs arising from it. In particular, the highest spatial indexes (IT) corresponds to A and B zones (Table 4). The IT (territorial index $-\mathrm{mc} / \mathrm{sqm}$ ) $=$ is the ratio between the volume maximum (V) in surface area ( ST ). Higher values of IT correspond to a more compact urban configuration, while low values of IT correspond to a dispersed configuration. Not surprisingly, the building densityurbanization is determined by the territorial (IT) and land (IF) indexes of manufacturability, which express the extent of the building volume for each square meter of land (ST) and land (SF), respectively. Where it is acquiring a city- oriented-dense compact configuration, it can achieve a greater environmental sustainability through lower energy requirements, as those related to construction materials like the aggregates.

TABLE IV. DISTRIBUTION OF IT (A, B, C AND F ZONES) IN THE MUNICIPALITIES OF CAGLIARI (EXCLUDED THE F ZONE), SANT'ANTIOCO

\begin{tabular}{|c|c|c|c|}
\hline urban areas & (ST) total area & $\begin{array}{l}\text { volume } \\
\text { building }\end{array}$ & $\begin{array}{l}\mathrm{IT}=\mathrm{V} / \mathrm{S} \mathrm{T} \\
(\mathrm{m} \mathrm{c} / \mathrm{m} \mathrm{q})\end{array}$ \\
\hline zona A & 1.237 .007 & 5.522 .043 & 4,46 \\
\hline zona B & 5.567 .059 & 28.317 .489 & 5,09 \\
\hline zona C & 2.846 .603 & 3.116 .655 & 1,09 \\
\hline totali & 9.650 .669 & 36.956 .187 & \\
\hline
\end{tabular}

\begin{tabular}{lcrr} 
SANT'ANTICO & & & \\
\hline urban areas & ((ST) total & $\begin{array}{l}\text { volume } \\
\text { building }\end{array}$ & \multicolumn{1}{l}{$\begin{array}{l}\text { IT }=\mathrm{V} / \mathrm{S} T \\
(\mathrm{~m} \mathrm{c} / \mathrm{m} \mathrm{q})\end{array}$} \\
zona A & 41.501 & 135.500 & 3,26 \\
zona B & 1.049 .823 & 2.544 .259 & 2,42 \\
zona C & 1.292 .324 & 884.862 & 0,68 \\
zona F & 6.459 .541 & 985.080 & 0,15 \\
\hline totali & 8.843 .189 & 4.549 .701 &
\end{tabular}

\begin{tabular}{|c|c|c|c|}
\hline \multicolumn{4}{|l|}{ TORTOLI } \\
\hline urban areas & (ST) total area & $\begin{array}{l}\text { volume } \\
\text { building }\end{array}$ & $\begin{array}{l}\mathrm{IT}=\mathrm{V} / \mathrm{S} \mathrm{T} \\
(\mathrm{m} \mathrm{c} / \mathrm{m} \mathrm{q})\end{array}$ \\
\hline zona A & 131.262 & 548737 & 4,18 \\
\hline zona B & 541.352 & 1.410 .815 & 2,61 \\
\hline zona C & 24.446 .262 & 2.119 .832 & 0,09 \\
\hline zona $F$ & 1.999 .102 & 629.484 & 0,31 \\
\hline totali & 27.117 .978 & 4.708 .868 & \\
\hline
\end{tabular}

AND TORTOLI - CITY URBAN PLANNING.

It should be specified that the situation observed in the municipalities of Cagliari, Sant'Antioco and Tortoli (and, similarly, in all the 362 municipalities of Sardinia) is mainly due to the regional legislation (FROM December 22, 1983 n. 2266 / U: Discipline of limits and relationships relating to the formation of new planning instruments and the revision of existing ones in the municipalities of Sardinia), similarly to what can be observed at the national level (DM April 2, 1968, n. 1444). The provisions of the regional legislation are resumed in Table 5.

Class I - Municipalities with more than 20,000 inhabitants;

Class II - municipalities of 10,000 to 20,000 inhabitants;

Class III - municipalities from 2,000 to 10,000 inhabitants;

Class IV - Municipalities up to 2,000 inhabitants. 
Proc. of the Third Intl. Conf. Advances in Civil, Structural and Mechanical Engineering- CSM 2015

Copyright (C) Institute of Research Engineers and Doctors, USA .All rights reserved. ISBN: 978-1-63248-062-0 doi: 10.15224/ 978-1-63248-062-0-82

TABLE V.

IT AND IF (MAX) INDICES FOR MUNICIPALITY CLASSES AND ZONES

\begin{tabular}{|c|c|c|c|}
\hline urban areas & $\begin{array}{l}\text { CLASSE } \\
\text { Comuni }\end{array}$ & $\begin{array}{l}\text { IT } \mathrm{max} \\
(\mathrm{m} \mathrm{c} / \mathrm{m} \mathrm{g})\end{array}$ & $\begin{array}{c}\text { IF } \max \\
(\mathrm{m} \mathrm{c} / \mathrm{m} \mathrm{q})\end{array}$ \\
\hline & I e II & & 7,00 \\
\hline \multirow[t]{2}{*}{ zona B } & III e IV & & 5,00 \\
\hline & I e II & 1,50 & \\
\hline \multirow[t]{2}{*}{ zona C } & III e IV & 1,00 & \\
\hline & I e II & & 0,75 \\
\hline zona F & III e IV & & 0,75 \\
\hline
\end{tabular}

Not being able to realistically promote the use of CDW at a regional scale, as a result of the distances that exist between production centers (Figure 3 ) and the destinations (over 30 $\mathrm{km}$, distance limit for aggregates established by regional regulations: VAS PRAE SARDINIA, 2014), it follows that the only way to limit the exploitation of mineral raw materials for aggregates should pass through an urban design that encourages compact over dispersed configurations (e.g. Sant'Antioco municipality). In addition, the processing facilities for recycled aggregates, although close to the places of destination, do not always provide sufficient material flows . This is the case of Tortolì and Cagliari .

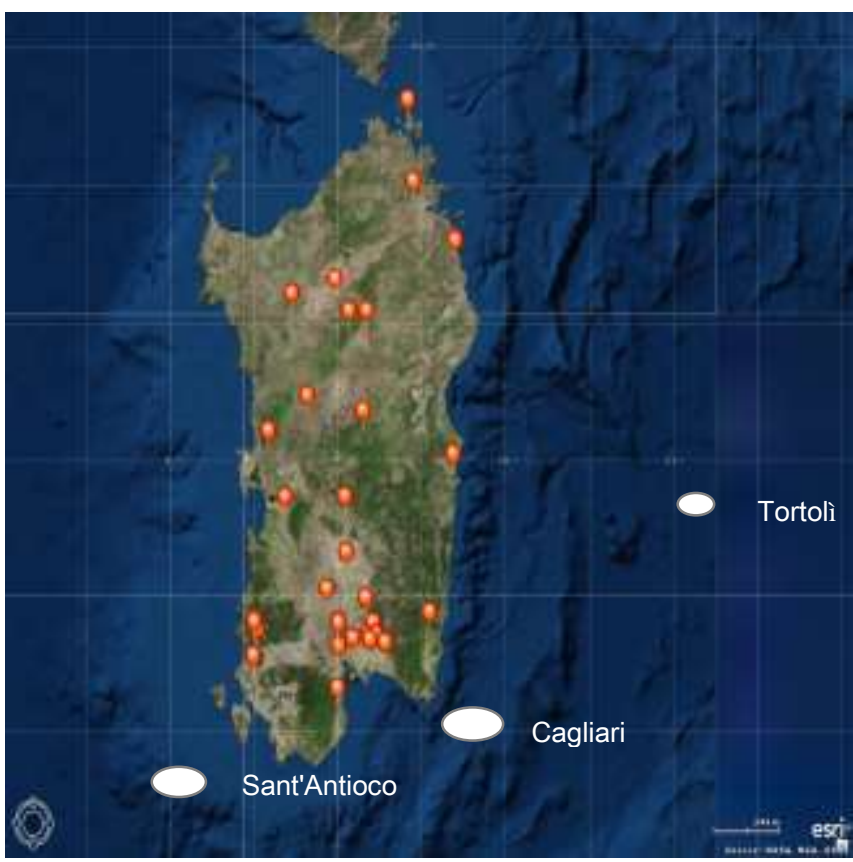

Figure 3 Localization of main processing facilities for recycled aggregates in Sardinia.

Moreover, forecasts of the local planning (PUC) usually fail to achieve the targets that the Regional Administration of Sardinia defined for the period 2015-2020, relative to the reuse of materials (objective 2015-20 = 55-70\%). This objective finds many obstacles that arise on the distance between the places of assignment and those of potential destination. Therefore rather than acting only on the reuse it is also preferred to act on the containment of the average requirement per capita per annum, making an appropriate reduction $(35 \%$,$) in line with the national guidelines of the$ containment of land consumption ratio (ISPRA, 2014). To promote the reduction in demand per capita on the implementation of the urban plans, a specific parameter to be associated with the PUC has to be introduced. This parameter can express the maximum demand for aggregates, which we will simply call FI-max (PUC): the needs of aggregates per capita resulting from PUC. In particular for a given Municipality (n) with PUC, the corresponding Fi-n (PUC), can occur in the following cases:

1) Fi-n (PUC) > Fi-max (PUC), condition of environmental incompatibility

2) Fi-n (PUC) = Fi-max (PUC), condition of environmental neutrality

3) Fi-n (PUC) < Fi-max (PUC), condition of environmental compatibility

The best forum for discussion about the definition of the parameter Fi-max (PUC) is certainly that of the VAS (Strategic Environmental Assessment) phase, deputy to the definition of environmental sustainability policies. In fact, according to Legislative Decree no. 152/2006 (art. 6 and subsequent amendments), all urban plans, including PUC and programs that can have significant effects on the environment, must undergo VAS, certainly including the mining activities.

In particular, the VAS of the PUC is understood as a process that accompanies the development and adoption of the same in order to ensure the integration of the environmental component. In fact the VAS requires that from the earliest stages of the PUC, it should be taken into account the environmental effects that the choices of the plan may imply in the local area and its surroundings.

For PUC of the municipalities involved in this study, three possible scenarios are formulated, with the exception of Cagliari, which constitutes a special case.

All scenarios are based on the compact configuration of zones $\mathrm{A}$ and $\mathrm{B}$, for which no reduction is expected about the needs for aggregates. In the remaining zones, they focused on the reduction of potential demand for aggregates. In particular:

- hypothesis 1: dispersed urban form for zone C (residential), and compact form for areas $\mathrm{F}$ (tourism);

- hypothesis 2: equivalent urban forms between zones $\mathrm{C}$ and $\mathrm{F}$;

- hypothesis 3: compact urban form for zone C, and dispersed urban form to areas F.

These hypotheses point to a still possible reduction of the demand for aggregates, when recycled aggregates in the process of construction cannot be used. 


\section{Conclusions:}

Compact and dispersed forms of cities match different requirements in terms of aggregates per capita. In particular, the compact form requires lower needs per capita. The parameter identified above gives the possibility of orienting the form of the city quantitatively defining a Fi max required for the implementation of a given PUC. In fact, the urban parameters of the PUC, together with those used in the VAS, do not allow to draw unambiguous controls of land use, partly due to the intense national and international debate which resulted in the proposal "Containment of soil consumption and reuse of built soil "(2014).

The correlations between mining, construction activity and urban planning can no longer be ignored or neglected, but must become part of the strategic objectives to be pursued. In particular, to find a point of balance between the form of the city and the delayed effects that it generates, is the key to understanding the present work.

Finally, control of aggregate demand is a new approach which is also due to base planning to pursue the strategic goals of environmental sustainability.

\section{REFERENCES}

[1] Badino V., Blengini G.A., and Garbarino E. (2006). Analisi tecnico economico - ambientale degli aggregati per l'industria delle costruzioni in Italia. Parte $2^{\circ}$. La stima dei fabbisogni, Geam, 3, 5-16.

[2] Balletto G. (ed.) (2005). La pianificazione sostenibile delle georisorse. Analisi e proposte per il dimensionamento del fabbisogno minerario di seconda categoria ad uso civile. La Sardegna come caso di studio. Franco Angeli, Milano, 1-195.

[3] BIO Intelligence service (2011). A project under the Framework contract ENV.G.4/FRA/2008/0112 SERVICE CONTRACT ON MANAGEMENT OF CONSTRUCTION AND DEMOLITION WASTE - SR1 Final Report.

[4] Bressi G., Volpe G., and Pavesi E. (2011). La produzione di aggregati riciclati da rifiuti inerti. I manuali di SARMa. Available at: http://www.sarmaproject.eu/index.php?id=1964 [last accessed: 30 January 2013].

[5] Circolare 15/07/2005 n. 5205 "Indicazioni per l'operatività nel settore edile, stradale e ambientale, ai sensi del D. M. 8 Maggio 2003, n. 203 "'

[6] Comune di Cagliari (2012). Programma Triennale delle Opere Pubbliche 2012/2014 (3-year Local Program of Public Works of Cagliari 2012-2014). Available at: http://www.comune.cagliari.it/ [last accessed: 30 January 2013].

[7] Comune di Cagliari (2002). Piano Urbanistico Comunale (Municipal Urban Plan of Cagliari), last revised in November 2010. Available at: http://www.comune.cagliari.it/ [last accessed: 30 January 2013].

[8] Decreto del Ministero delle Infrastrutture 14 gennaio 2008, "Norme Tecniche per le Costruzioni”.

9] Decreto del Ministero dell'Ambiente e della Tutela del Territorio 8 maggio 2003, n.203, "Norme affinchè gli uffici pubblici e le società a prevalente capitale pubblico coprano il fabbisogno annuale di manufatti e beni con una quota di prodotti ottenuti da materiale riciclato nella misura non inferiore al 30\% del fabbisogno medesimo".

[10] European Parliament and Council (2008). Directive 2008/98/EC on waste.

[11] European Parliament, Policy Department Economy and Science DG Internal Policies (2008). Impact assessment of recycling targets in the waste framework directive (IP/A/ALL/FWC/2006-105/Lot4/C1/SC3), Brussels.
[12] Fondazione Benetton Studi Ricerche and IBA (Internationale Bauausstellung Fürst-Pückler-Land) [eds]. (2005). Transforming landscapes. Grossräschen: Internationale Bauausstellung FürstPückler-Land

[13] Tiess, G. (2010). Minerals policy in Europe: Some recent developments. Resour. Policy, vol. 35, 190-198.

[14] Furcas C. and Balletto G. (2012). Effects of quarrying activity and the construction sector on environmental sustainability. A brief report on the rapid growth of emerging Central and Eastern European States, Diamante Applicazioni\&Tecnologia, vol. 70, 74-81.

[15] Furcas C. and Balletto G. (2013). Converting waste from the dimension stone industry into sustainable environmental resources. Current trends, market opportunities and future outlooks, Proceedings 28th International Conference on Solid Waste Technology and Management, Philadelphia, USA, 104-115.

[16] Gisotti G. (2008). Le cave. Recupero e pianificazione ambientale. Dario Flaccovio Editore, Palermo.

[17] Pani L. and Francesconi L. (2011). Influence of replacement percentage of recycled aggregates on recycled aggregate concrete properties. Fib Symposium, Prague 2011.

[18] Pani L., Balletto G., Naitza S., Francesconi L., Trulli N., Mei G., and Furcas C. (2013). Evaluation of mechanical, physical and chemical properties of recycled aggregates for structural concrete. Proceedings Sardinia 2013, 14th International Waste Management and Landfill Symposium, CISA publisher, Cagliari.

[19] Programma Olimpico Torino 2006 (2000). Piano complessivo degli inerti. In D.G.R. Piemonte n.61-1774 del 18 dicembre 2000 Procedure e contenuti per la valutazione di impatto ambientale del piano degli interventi per i Giochi Olimpici Invernali Torino 2006.

[20] RAS (Regione Autonoma della Sardegna) (2012). Rapporto Ambientale, adottato con Delibera del 18 aprile 2012, n. 16/22, Adozione del Piano Regionale di Gestione dei Rifiuti Speciali della Sardegna e degli elaborati connessi alla Valutazione Ambientale Strategica e alla Valutazione di incidenza ambientale. Available at: http://www.regione.sardegna.it [last accessed: 30 January 2013]

[21] Spies S., German Technical Cooperation (2009). 3R in Construction and Demolition Waste (CDW), potentials and constraints. Inaugural Meeting of the Regional 3R Forum in Asia, Tokyo, Japan. Available at: www.uncrd.or.jp [last accessed: 30 January 2013].

[22] UEPG (European Aggregates Association) (2009). Position Paper on "The Raw Material Initiative", UEPG aisbl, Brussels. Available at: http://www.uepg.eu [last accessed: 30 January 2013].

[23] UEPG (European Aggregates Association) (2012). Annual Review 2011-2012, UEPG aisbl, Brussels. Available at: http://www.uepg.eu [last accessed: 30 January 2013].

[24] Università di Bologna and Provincia di Bologna (2002). Piano Infraregionale delle Attività Estrattive 2002-2012.

\section{Ginevra Balletto}

1Cagliari University

Italy

\section{Carla Furcas}

Cagliari University

Italy 
Proc. of the Third Intl. Conf. Advances in Civil, Structural and Mechanical Engineering- CSM 2015

Copyright (C) Institute of Research Engineers and Doctors, USA .All rights reserved.

ISBN: 978-1-63248-062-0 doi: 10.15224/ 978-1-63248-062-0-82

\section{Giovanni Mei}

Cagliari University

Italy

\section{Stefano Naitza}

Cagliari University

Italy 